\title{
The Application of Interactive Media Powerpoint to Improve The Ability of Students in Reading on The Text Conclude The Matter
}

\author{
Muhayati \\ SDN Pranten 1 \\ messutmuha@gmail.com
}

\section{Article History}

accepted 14/11/2020

approved $21 / 11 / 2020$

published 26/11/2020

\begin{abstract}
The purpose of this research is to increase of students ability in concluded the reading on the text in Indonesian Language in primary school class III using powerpoint interactive media. The class action is research used by two cycles, with every cycle consisting of one meeting. The stage of each cycle is planing, implementation, observation and reflection. The meeting is about the development of the test is conducted in inferring students reading text. In cycle I students be completed after doing test $40 \%$ and in cycle II students be completed is $80 \%$. This result indicates that uses the media powerpoint interactive can increase the students especially grade III Indonesian Language at SDN Pranten 01
\end{abstract}

Keywords: Learning outcomes, powerpoint interactive, Concluded reading the text, Indonesian Language

\begin{abstract}
Abstrak
Abstrak dalam bahasa Indonesia mengikuti kaidah dalam Pedoman Umum Ejaan Bahasa Indonesia (PUEBI)Tujuan penelitian ini adalah untuk meningkatkan kemampuan siswa dalam menyimpulkan masalah pada teks bacaan pada mupel Bahasa Indonesia di sekolah dasar kelas III dengan menggunakan Media Powerpoint Interaktif. Penelitian yang digunakan adalah Penelitian Tindakan Kelas sebanyak dua siklus, dengan setiap siklus terdiri dari satu kali pertemuan. Tahapan setiap siklusnya adalah perencanaan, pelaksanaan, observasi dan refleksi. Setiap pertemuan dilakukan tes untuk mengetahui perkembangan peserta didik dalam menyimpulkan teks bacaan. Pada siklus I peserta didik yang tuntas setelah melakukan tes sebesar $40 \%$ dan pada siklus II peserta didik yang tuntas adalah $80 \%$. Hasil ini menunjukkan bahwa menggunakan Media Powerpoint Interaktif dapat meningkatkan hasil peserta didik pada mupel Bahasa Indonesia Kelas III di SDN Pranten 01.
\end{abstract}

Kata kunci: Hasil Belajar, Powerpoint Interaktif, menyimpulkan teks bacaan, Bahasa Indonesia

Social, Humanities, and Education Studies (SHEs): Conference Series https://jurnal.uns.ac.id/shes

p-ISSN 2620-9284

e-ISSN 2620-9292 


\section{PENDAHULUAN}

Bahasa Indonesia merupakan mata pelajaran yang wajib disetiap jenjang pendidikan baik SD/MI, SMP maupun SMA/MA hingga ke Perguruan Tinggi.Tujuan pembelajaran Bahasa Indonesia sesuai dengan keterampilan kebutuhan, dan minatnya, sedangkan bagi guru adalah untuk mengembangkan potensi bahasa Indonesia siswa, serta lebih mandiri dalam menentukan bahan ajar kebahasaan sesuai dengan kondisi lingkungan sekolah dan kemampuan siswa. BSNP (2006).

Pelajaran bahasa Indonesia mulai dikenalkan di tingkat sekolah dasar sejak kelas 1 SD. Mata pelajaran bahasa Indonesia diberikan disemua jenjang pendidikan formal. Standar kompetensi mata pelajaran bahasa Indonesia bersumber pada hakikat pembelajaran bahasa yaitu belajar bahasa (belajar berkomunikasi) dan belajar sastra (belajar menghargai manusia dan nilai-nilai kemanusiaannya. Oleh karena itu, pembelajaran bahasa Indonesia mengupayakan peningkatan kemampuan siswa untuk berkomunikasi secara lisan dan tertulis serta menghargai karya cipta bangsa Indonesia (Hartati, 2003).

Pembelajaran bahasa Indonesia di sekolah diharapkan membantu siswa mengenal dirinya, budayanya dan budaya orang lain, mengemukakan gagasan dan perasaan, berpartisipasi dalam masyarakat yang menggunakan bahasa tersebut dan menemukan serta menggunakan kemampuan analitis dan imajinatif yang ada dalam dirinya. Akan tetapi di SDN Pranten 01 pembelajaran Bahasa Indonesia masih mengalami kesulitan.

Menurut Mulyasa "2008" Hasil belajar ialah prestasi belajar siswa secara keseluruhan yang menjadi indikator kompetensi dan derajat perubahan prilaku yang bersangkutan. Kompetensi yang harus dikuasai siswa perlu dinyatakan sedemikian rupa agar dapat dinilai sebagai wujud hasil belajar siswa yang mengacu pada pengalaman langsung.

Upaya mengatasi hasil belajar Bahasa Indonesia telah dilakukan oleh pemerintah dan sekolah, Seperti penyempurnaan kurikulum, pengadaan buku paket, dan pengadaan buku bacaan, namun pada siswa kelas 3 SDN Pranten 01 mengalami kesulitan dalam meningkatkan hasil belajar Bahasa Indonesia materi menyimpulkan masalah pada teks bacaan. Hal tersebut didasarkan pada data nilai di sekolah yang menunjukkan nilai Bahasa Indonesia masih rendah dibandingkan muatan pelajaran lain. Nilai rata - rata tes yang hanya 50 padahal kriteria ketuntasan minimal 65 .

Selama ini ketika mengajar Bahasa Indonesia guru hanya menggunakan metode konvensional. Menurut Djamarah (1996), metode pembelajaran konvensional adalah metode pembelajaran tradisional atau disebut juga dengan metode ceramah, karena sejak dulu metode ini telah dipergunakan sebagai alat komunikasi lisan antara guru dengan anak didik dalam proses belajar dan pembelajaran, sehingga kurangnya interaksi siswa. Apalagi ditambah dengan adanya Penyebaran pandemi virus corona atau COVID-19 yang membuat sektor pendidikan seperti sekolah membatasi proses pembelajaran secara tatap muka. Sehingga mengakibatkan siswa semakin kurang paham pada materi menyimpulkan masalah pada teks bacaan.

Sebagai alternatif solusi masalah agar guru dalam mengajarkan keterampilan menulis agar mudah dipahami maka guru harus menggunakan berbagai media pembelajaran, yang salah satunya adalah media powerpoint interaktif. Menurut Miarso (2004) berpendapat bahwa "Media pembelajaran adalah segala sesuatu yang digunakan untuk menyalurkan pesan serta dapat merangsang pikiran, perasaan, perhatian, dan kemauan si belajar sehingga dapat mendorong terjadinya proses belajar"

Microsoft Office Power Point adalah sebuah program komputer untuk presentasi yang dikembangkan oleh Microsoft, disamping Microsoft word dan excel yang telah dikenal banyak orang (Rusman dkk, 2013: 300). Program power point merupakan salah satu software yang dirancang khusus untuk mampu menampilkan program 
multimedia menarik, mudah dalam pembuatan, mudah dalam penggunaan dan relatif murah, karena tidak membutuhkan bahan baku selain alat untuk penyimpanan data (Rusman dkk, 2013: 301).

Interaktif adalah hal yang terkait dengan komunikasi dua arah / suatu hal saling melakukan aksi, saling aktif dan saling berhubungan serta mempunyai timbal balik antara satu dengan lainnya (Warsita : 2008).

Berdasarkan latar belakang di atas maka peneliti menggunakan media power point interaktif untuk membantu siswa yang mengalami kesulitan dalam belajar menyimpulkan masalah pada teks.

\section{METODE}

Penelitian tindakan kelas merupakan terjemahan dari classroom action research (CAR) dengan penerapan media powerpoint interaktif. I.G.A.K Wardani, Kuswaya Wihardit; Noehi Nasution merumuskan pengertian penelitian tindakan kelas sebagai berikut : "penelitian tindakan kelas adalah penelitian yang dilakukan oleh guru didalam kelasnya sendiri melalui refleksi diri, dengan tujuan untuk memperbaiki kinerjanya sebagai guru, sehingga hasil belajar siswa menjadi meningkat. Sehingga untuk meningkatkan hasil belajar siswa peneliti menggunakan media powerpoint interaktif. Penelitian dilaksanakan di SDN Pranten 01 pada siswa kelas III Tahun Pelajaran 2020/2021 dalam dua siklus. Siklus I dilaksanakan pada 16 November 2020 dan siklus II dilaksanakan pada 23 November 2020. Teknik pengumpulan data dilakukan dengan cara tes tertulis

\section{HASIL DAN PEMBAHASAN}

Pada siklus I pembelajaran dilaksanakan satu kali pertemuan dalam pelaksanannya diberikan tes uraian untuk mengetahui perkembangan peserta didik selama pembelajaran. Siklus I membahas materi Memiliki Tubuh Sehat dan menyimpulkan teks bacaan. Pembelajaran ini menerapakan Media Powerpoint Interaktif. Berdasarkan data hasil penelitian pada siklus I mengenai hasil belajar Mupel Bahasa Indonesia dengan Penerapan Media Powerpoint Interaktif dalam proses pembelajaran diperoleh data sebagai berikut

Tabel 1. Hasil Belajar Peserta DIdik Siklus I

\begin{tabular}{cccc}
\hline Intreval Nilai & Frekuensi & Frekuensi Relatif & Kualifikasi \\
\hline $100-109$ & & & \\
$90-99$ & & & \\
$80-89$ & 2 & $40 \%$ & Tuntas \\
$70-79$ & 1 & $20 \%$ & Tuntas \\
$60-69$ & 1 & $20 \%$ & Tidak \\
$50-59$ & 1 & $20 \%$ & Tuntas \\
Tidak \\
$40-49$ & & & Tuntas \\
$30-39$ & 5 & $100 \%$ & \\
Jumlah & & $60 \%$ & \\
Presentase Ketuntasan & & & \\
Klasikal & & &
\end{tabular}

Hal ini menunjukkan bahwa $60 \%$ siswa mangalami ketuntasan balajar, dan $30 \%$ siswa tidak tuntas. Akan tetapi ketuntasan belajar Mupel Bahasa Indonesia dengan 
Penerapan Media Powerpoint Interaktif tersebut belum mencapai target yang diinginkan yang tercantum dalam indikator kerja yaitu sekurang-kurangnya $80 \%$ dari ketuntasan belajar klasikal siswa.

Dari hasil pengamatan Peneliti ternyata Penerapan Media power point pada Menyimpulkan Masalah Pada Teks Bacaan Siswa Kelas III SDN Pranten 01 tampak adanya kemajuan dibanding pembelajaran sebelumnya. Namun secara proses perbaikan pembelajaran belum menampakkan hasil yang sesuai dengan tujuan pembelajaran, terlebih lagi setelah diadakan observasi masih banyak siswa yang masih mengalami kesulitan dalam menyimpulkan masalah pada teks bacaan. Pada tahap ini peneliti menilai bahwa peserta didik kurang diberikan waktu yang cukup dalam mengerjakan dan kurangnya pemahaman tehadap membaca. Melihat evaluasi pada siklus I tersebut maka perlu diadakan perbaikan pembelajaran Siklus II

Pada siklus II juga masih membahas materi yang sama seperti siklus I. berikut hasil belajar siklus II yang dapat dilihat pada table berikut ini.

Tabel 2. Hasil Belajar Peserta Dldik Siklus II

\begin{tabular}{cccc}
\hline Intreval Nilai & Frekuensi & $\begin{array}{c}\text { Frekuensi } \\
\text { Relatif }\end{array}$ & Kualifikas \\
\hline $100-109$ & & & \\
$90-99$ & 2 & $40 \%$ & Tuntas \\
$80-89$ & 1 & $20 \%$ & Tuntas \\
$70-79$ & 1 & $20 \%$ & $\begin{array}{c}\text { Tuntas } \\
60-69\end{array}$ \\
$50-59$ & 1 & $20 \%$ & Tidak Tuntas \\
$40-49$ & & & \\
$30-39$ & 5 & $100 \%$ & \\
Jumlah & & & \\
Rerata & & $80 \%$ & \\
Presentase Ketuntasan & & & \\
Klasikal & & & \\
\hline
\end{tabular}

Berdasarkan tabel di atas maka terjadi peningkatan pembelajaran pada setiap peserta didik.meskipun belum sepenuhnya tuntas karena kecerdasan setiap anak berbeda. J.P Chaplin ( Mujib, 2002: 318) merumuskan tiga defenisi kecerdasan, yaitu: 1) Kemampuan menghadapi dan menyesuaikan diri terhadap situasi baru secara cepat.

dan efektif, 2) kemampuan menggunakan konsep abstrak secara efektif, yang meliputi empat unsur seperti memahami, berpendapat, mengontrol dan mengkritik, 3) kemampuan memahami pertalian-pertalian dan belajar dengan cepat sekali.

Dari hasil pengamatan Peneliti ternyata Penerapan Media Powerpoint Interaktif pada Menyimpulkan Masalah Pada Teks Bacaan Siswa Kelas III SDN Pranten 01 bisa dikatakan mempunyai pengaruh terhadap hasil belajar siswa.Akan tetapi perlu diperbaiki pada saat proses evaluasi. Pada tahap ini peneliti menilai bahwa peserta didik kurang memahami tehadap membaca

\section{SIMPULAN}

Penerapan Media Powerpoint interaktif dapat meningkatkan kemampuan menyimpulkan masalah pada teks di kelas III SDN Pranten 01 Mupel Bahasa Indonesia. Peningkatan terjadi karena pembelajaran dikemas secara interaktif menggunakan media powerpoint sehingga peserta didik selalu teringat terhadap materi yang disampaikan. Berdasarkan penelitian yang telah dilaksanakan hal yang harus 
dikuasai guru adalah penguasaan IT sehingga dapat menerapkan Powerpoit Interaktif. Dengan media powerpoint interaktif kemampuan mengingat peserta didik menjadi bertambah.

Bahtraedu.2015.Media

\section{DAFTAR PUSTAKA}

https://bahtraedu wordpress.com/2015/05/02/media-pembelajaran-power-point/. html (diakses 6 November 2020).

BSNP. 2006. Permendiknas RI No. 22 Tahun 2006 tentang Standar Isi untuk Satuan Pendidikan Dasar dan Menengah. Jakarta

Dosen Pendidikan 2.2020. Pengertian Hasil Belajar. https://www.dosenpendidikan.co.id/hasil-belajar/

Iriawan, Sandi Budi.2019. Pendalaman Materi Pembelajaran di SD Berbasis TIK. Bandung : Kementrian Pendidikan dan Kebudayaan.

Jaririndhu.2020. Faktor-faktor yang Mempengaruhi Belajar Menurut Beberapa Ahli. https://jaririndu.blogspot.com/2017/08/faktor-faktor-yang-mempengaruhibelajar.html

Makplus,Om.2020. Definisi atau Pengertian Media Pembelajaran Menurut Ahli. http://www.definisi-pengertian.com/2015/10/definisi-pengertian-media pembelajaranahli.html\#: :text=Menurut\%20Miarso\%20(2004)\%20berpendapat \%20bahwa,dapat\%20mendorong\%20terjadinya\%20proses\%20belajar\%E2\%80 $\% 9 \mathrm{D}$.

Pengertian Interaktif. https://www.pengertianmenurutparaahli.net/pengertian-interaktif/

Uhkjklkklm. 2016. Pengertian Dan Tujuan Bahasa Indonesia Menurut Para ahli. http://pengertianahlidaninfo.blogspot.com/2016/09/pengertian-dan-tujuan-bahasaindonesia.html\#: :text=Berdasarkan\%20pendapat\%20tersebut\%20dapat\%20disim pulkan,pembelajaran\%20yang\%20dilaksanakan\%20secara\%20terpadu.\&text=Ru ang $\% 20$ lingkup $\% 20$ mata $\% 20$ pelajaran $\% 20$ bahasa,berbicara\%2C\%20membaca\% 2C\%20dan\%20menulis 